\title{
Expert System for Diagnosis of Sexual Diseases (Paraphilia) Using Method Dempster Shafer
}

\author{
Nince Rianto Gulo ${ }^{1}$, Bosker Sinaga ${ }^{2}$ \\ 1,2Informatics Engineering, STMIK Pelita Nusantara, Sumatera Utara, Indonesia
}

\section{Article Info}

\section{Article history:}

Received Dec 10, 2021

Revised Dec 22, 2021

Accepted Jan 13, 2022

\section{Keywords:}

Expert System;

Data Mining.

Dempster Shafer;

Sexual Diseases

\begin{abstract}
Sexual behavior disorder (paraphilia) is sexual behavior that is unacceptable in society. The lack of knowledge and the many obstacles to getting information about early and independent detection of the community about sexual deviations and ignorance of the community in responding to deviations are also factors that cannot be handled early The main symptoms of this paraphilia disease are repeated childhood traumatic, coming from a family that is too restrictive or too disruptive to children in sexual behavior, and has a disorder in sexual relations since childhood. There are several types of sexual disorders (paraphilia) including Voyeuristic, Exhibitionistic, Frotteuristic, Sexual Masochim, Sexual Sadism, Pedophilic, Fetishistic and Transvestic. The Dempster Shafer method provides space for the expert in providing the value of trust in his knowledge. Based on the problems above, a Webbased system will be built that functions to help the community conduct independent consultations about disturbances that can be accessed with a wide range and unlimited time. The system built using PHP and MySQL programming as a database. The method used for tracing is the dempster shader. While the results of the diagnosis will inform about the results of the diagnosis containing a list of symptoms entered, information on the results of the rules about the disorder suffered and information about possible treatments that can be done.
\end{abstract}

This is an open access article under the CC BY-NC license.

\section{Corresponding Author:}

Bosker Sinaga,

Informatics Engineering,

STMIK Pelita Nusantara Medan,

Jl. Iskandar Muda No. 1 Medan, 20154, Indonesia.

Email: boskersinaga@gmail.com

\section{Introduction}

In accordance with the development of the times both in terms of science and information technology today. The rapid development of information technology today encourages people to use this technology in diagnosing a disease, one of which is a sexual disorder (Paraphilia). Technological progress is something that we cannot avoid in life, because technological advances will increasingly run in accordance with scientific advances.

The role of the system in diagnosing sexual disorders (Paraphilia) is very important to provide fast, precise and accurate information. The public in general does not know much about sexual disorders (paraphilia) so that in order to carry out treatment of sexual disorders (Paraphilia) in detail experienced by sufferers, it is necessary to have the help of an expert in order to obtain accurate and reliable diagnostic results for the sexual disorder (Paraphilia) experienced, especially people who come from rural areas who lack knowledge about what is meant by sexual disorder (Paraphilia) and 
how to diagnose and treat it. For this reason, in diagnosing the disease, an expert system is used using the Dempster Shafer method.

The term Paraphilia comes from the Greek, para meaning "On the Other Side" and Philos meaning "Love", so paraphilia is defined as sexual activity that is not in general, or experiencing sexual perversion (Daud, 2016). Sexual disorders (Paraphilia) refer to sexual behavior that is considered deviant or violates the rules that have been set in a country such as legal norms, religious norms, and customs. Paraphilia is a type of sexual disease disorder that is included in an emotional disorder that involves behavior, urges, or fantasies so that it spreads into a mental disorder, this is due to continuous and intense deviant sexual desires.

Dempster Shafer is a theory developed by Arthur P. Dempster and Glenn Shafer which is generally written in an interval. So the Dempster Shafer method is a mathematical theory to perform proofs based on belief functions and plausible reasoning (Utomo \& Suprapto, 2017).

This study aims to assist the general public in diagnosing sexual disorders (paraphilia), how to apply the Dempster Shafer method in expert system applications, and how to design and build a webbased expert system to diagnose sexual disorders using the Dempster Shafer method (Bhaskara, Hidayat, \& Muflikhah, 2019).

This study uses a literature review from several previous research journals. The research journal is in the form of an expert system for diagnosing sexually transmitted diseases in men with the Dempster Shafer method. Then the research that uses the Dempster Shafer method with the title Expert System for Diagnosing Children's Mental Disorders Using the Dempster Shafer Method, this study diagnoses metal disorders in children. Types of mental disorders in children are divided into schizophrenia, dynamic disorder, social phobia, posttraumatic stress disorder, separation anxiety disorder, generalized anxiety disorder, autism spectrum disorder, and manic episode (Hastari \& Bimantoro, 2018).

The next research journal is the Dempster Shafer Method for Detecting Mental Disorders: Schizophrenia and Psychotics (Gozali \& Jollyta, 2019). This study diagnoses mental illness specifically schizophrenia and psychotic. Research entitled Dempster-Shafer Method for Early Diagnosis of Schizophrenia Mental Disorders Based on Expert Systems. This study diagnoses schizophrenic mental disorders, which consist of six types of diseases, namely paranoid, heberphrenic, catatonic, simplex, post-schizophrenic depression, and residual with forty-three types of symptoms (Hairani, Kurniawan, Abd Latif, \& Innuddin, 2021).

Then a research journal in the form of the application of the Dempster Shafer method to diagnose diseases caused by the bacterium Treponema pallidum. This disease is caused by the bacterium Treponema pallidum (Sembiring \& Sinaga, 2017). Furthermore, in the study entitled Expert System Diagnosis of Personality Disorders Using the Dempster Shafer Method. This study diagnoses human personality disorders using the Dempster Shafer method. The type of personality disorder of a person consists of paranoid, schizoid, histrionic, schizotypal, narcissistic, antisocial, borderline, avoidant and obsessive-compulsive disease caused by thirty-nine symptoms of the disease (Yuwono, Fadlil, \& Sunardi, 2019). Next is a research journal entitled Expert System for Diagnosing Personality Disorders Using the Web-Based Dempster Shafer Method. This study diagnoses a person's personality disorder consisting of paranoid, schizoid, schizotypal, histrionic, narcissistic, antisocial, borderline (threshold), avoidan (avoiding), dependent, and obsessive-compulsive disorder caused by seventy-five symptoms (Rahmadhani, Fauziah, \& Aningsih, 2020).

System for Diagnosis of Sexually Transmitted Diseases in Men Using Forward Chaining and Dempster Shafer Methods. This study compares two methods, namely forward chaining and demspter shader. Based on the comparison of the two methods, it produces a very high accuracy of $94.2 \%$ (Wiyandra, 2019). Next is a research journal entitled Expert System for Diagnosing Personality Disorders Using the Web-Based Dempster Shafer Method. This study diagnoses a person's personality disorders consisting of paranoid, schizoid, schizotypal, histrionic, narcissistic, antisocial, borderline (threshold), avoidan (avoiding), dependent, and obsessive-compulsive symptoms caused by seventyfive symptoms. System for Diagnosis of Sexually Transmitted Diseases in Men Using Forward Chaining and Dempster Shafer Methods. This study compares two methods, namely forward chaining and demspter shader. Based on the comparison of the two methods, it produces a very high accuracy of 
94.2\%. Expert System Application To Diagnose Neurological Disorders With Android-Based Dempster Shafer Method. This expert system specifically diagnoses neurological disorders such as epilepsy, meningitis, trigeminal neuralgia, Parkinson's, stroke, migraine, vertigo with thirty-four types of symptoms. The last research journal used in this study is the Implementation of the Dempster Shafer Method for Detecting Diabetes Mellitus. In this study, three types of diabetes mellitus were detected.

\section{Method}

\subsection{Research Framework}

To assist in the preparation of this research, it is necessary to have a systematic research framework arrangement.

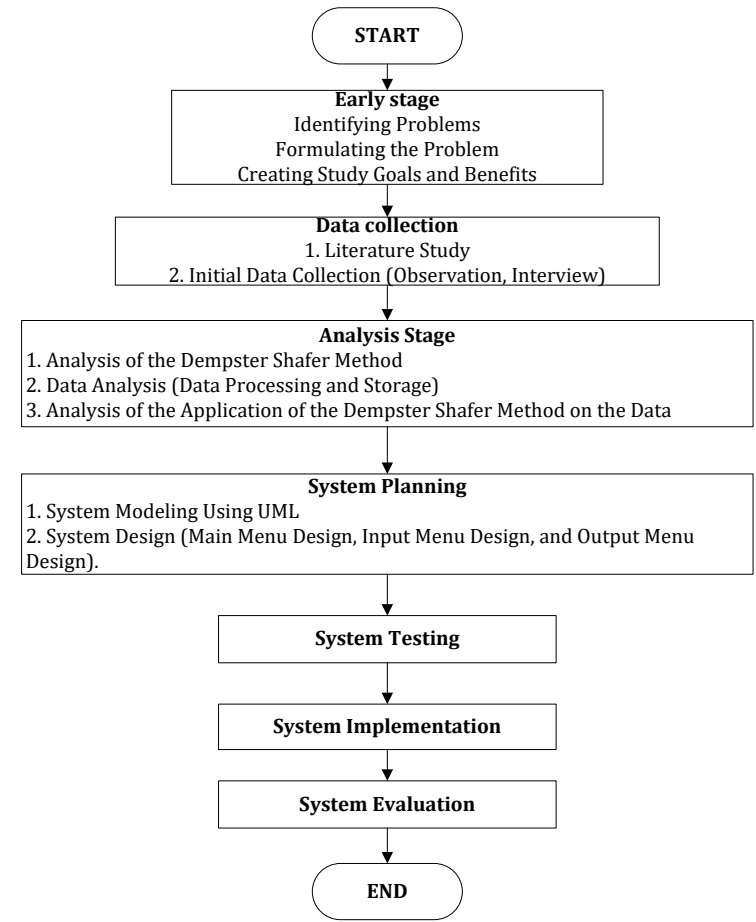

Fig 1. Research Framework

\subsection{Research Framework}

The description of the framework is a further explanation regarding the description of the process of the research framework carried out, along with the explanation:

a. Early Stage

1) Identifying Problems

This stage aims to find out what are the problems that arise in the diagnosis of sexual disorders (paraphilia).

2) Formulating the Problem

Formulate problems that will be developed and will be discussed in research for an expert system for diagnosing sexual disorders (paraphilia) using the Dempster Shafer method.

3) Creating Study Goals and Benefits

This stage aims to build an expert system for diagnosing sexual disorders and what are the benefits for the general public who suffer from sexual disorders (paraphilia).

b. Data Collection

At this stage of data collection is done by means of observation, namely observing directly the activities of diagnosing sexual disorders (paraphilia) that are running and conducting interviews with respondents. The respondents of this study were Mr. dr. Muhammad Anwar 
Lubis, Sp. KK (K) at the "Zaskia Husada" Inpatient Primary Clinic in Lubuk Pakam, Deli Serdang Regency, North Sumatra Province.

c. Analysis Stage

1) Analysis Dempster Shafer Method

This stage analyzes whether the Dempster Shafer method is appropriate to use in solving problems in building an expert system for diagnosing sexual disorders (paraphilia) using the Dempster Shafer method.

2) Data Analysis (Data Processing and Storage)

The stage for manipulating data into information, where the information will be stored data until the final result of processing because information is the result of processing data in a certain form that is more meaningful than an activity or event.

3) Analysis of the Aplication of the Dempster Shafer Method on the Data

This stage analyzes the application of the Dempster Shafer method with the aim of describing the initial design of the system to be used as a reference in system design.

\section{d. System Planningg}

This stage is designing the system using UML (Unified Modeling Language) modeling and also designing the interface of the system to be built later, such as the main menu design, data input menu design and information output menu design as well as HIPO (Hierarchy Input Process and Output) from the existing system built.

e. System Testing

Testing the system to determine whether the designed system is in accordance with user needs or not

f. System Implementation

At this stage, the new information system is placed into the existing system (old system). At this stage, the existing database and network will be created.

g. System Evaluation

Stage to assess / measure against the system designed whether the system is designed in accordance with the objectives of system design. If the system is in accordance with the desired design, the system is ready for operation and system maintenance is always carried out.

\section{Result and Discussion}

In designing this expert system by taking sources from experts or doctors, books and journals.

a. Type of Disease

\section{TABLE 1}

TYPES OF SESXUAL DISORDERS (PARAPHILIA)

\begin{tabular}{|c|c|c|}
\hline Code & Disease Name & Definition of Disease \\
\hline P001 & Voyeuristic Disorder & $\begin{array}{l}\text { Sexual disorder characterized by sexual arousal when } \\
\text { observing naked people or sexual activity. }\end{array}$ \\
\hline P002 & Exhibitionistic Disorder & $\begin{array}{l}\text { This sexual deviation is characterized by when a person } \\
\text { achieves satisfaction by showing his genitals to give a shock, } \\
\text { surprise, and even impression to the viewer. }\end{array}$ \\
\hline P003 & Frotteuristic Disorder & $\begin{array}{l}\text { Patients with this sexual disorder become sexually aroused } \\
\text { when rubbing their genitals on other people in public places in } \\
\text { a condition where the victim is not concentrating. }\end{array}$ \\
\hline P004 & $\begin{array}{l}\text { Sexual Masochim } \\
\text { Disorder }\end{array}$ & $\begin{array}{l}\text { This type of sexual deviation is indicated by the characteristics } \\
\text { of getting sexual satisfaction when he is tortured or humiliated } \\
\text { during sexual intercourse. }\end{array}$ \\
\hline P005 & Sexual Sadism Disorder & $\begin{array}{l}\text { This type of sexual deviance disorder is feeling satisfied when } \\
\text { he sexually abuses other people. }\end{array}$ \\
\hline P006 & Pedophilic Disorder & $\begin{array}{l}\text { Sexual disorders characterized by disturbances in the form of } \\
\text { impulses }\end{array}$ \\
\hline P007 & Fetishistic Disorder & $\begin{array}{l}\text { Fetishistic is a sexual disorder that desires inanimate objects, } \\
\text { for example: clothes, shoes, or underwear. }\end{array}$ \\
\hline P008 & Transvestic Disorder & $\begin{array}{l}\text { This sexual deviance means a heterosexual man who prefers to } \\
\text { wear women's clothes for sexual gratification. }\end{array}$ \\
\hline
\end{tabular}


b. Solution and Treatment

TABLE 2

SOLUTION AND TREATMENT

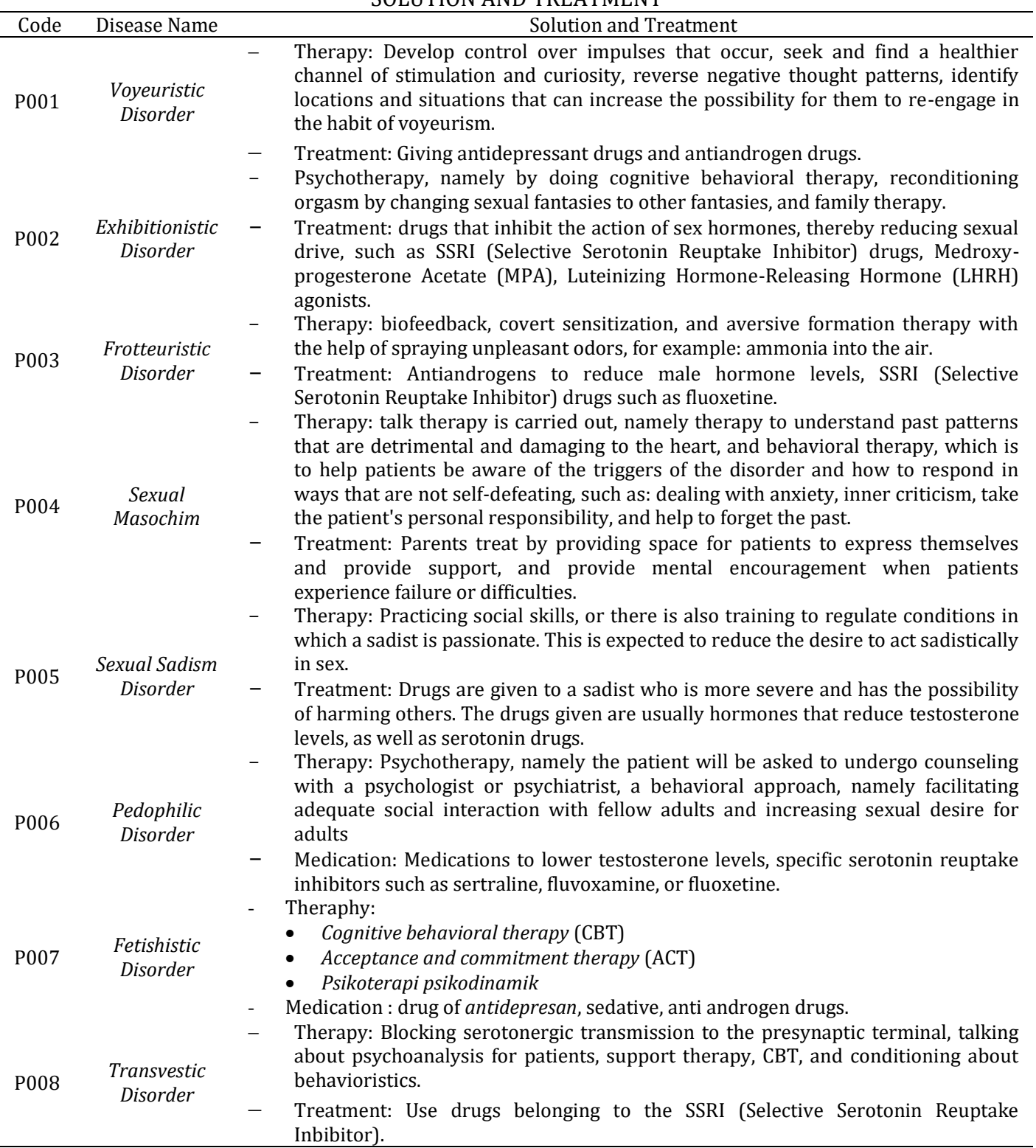

c. Disease Symptoms

TABLE 3

SISEASE SYMPTOMS

\begin{tabular}{ccc}
\hline Code & Symptoms Disease & Diseases \\
\hline G001 & $\begin{array}{l}\text { Experiencing intense and repeated sexual arousal from peering at others who are undressed, } \\
\text { undressed, or engaged in sexual activity for six months as a manifestation of fantasies, urges } \\
\text { or actions. }\end{array}$
\end{tabular}

G002

Usually will peek while fantasizing sexually and masturbating, but is not interested in having sex with the person he is peeking at.

Code 


\begin{tabular}{clc}
\hline Code & \multicolumn{1}{c}{ Symptoms Disease } & Diseases \\
\hline G003 & $\begin{array}{l}\text { Usually will peek while fantasizing sexually and masturbating, but is not interested in having } \\
\text { sex with the person he is peeking at. }\end{array}$ & P002
\end{tabular}
sex with the person he is peeking at.

G004 Fantasy, sexual urges, or behavior cause significant impairment or impairment in social, occupational, or other important functions.

G005 Sometimes masturbates when exposing himself, or when fantasizing about exposing himself Intense sexual fantasies, desires, and arousal centered on touching other people's body parts

G006 without consent or rubbing body parts, especially the genitals, on another person and usually from behind.

The act of froteurism is usually repeated and occurs in crowded public spaces, such as trains, buses, elevators, and even crowded streets.

When committing this act of sexual harassment, the perpetrator usually imagines having a personal relationship based on affection with the victim, but will run away afterward.

G009 Work to exhaustion, be hard on yourself when you push yourself to the limit and exceed it

G010 Feeling humiliated inside, but never showing it to others

G011 Feeling unloved and having to work hard to be accepted by those around you, and feeling that the effort you put in is never enough

G012 The inner voice or criticism attacks no matter what

G013 Feeling unable to say no or to assert yourself, instead agreeing with grumbling inside Having complaints about lots in life, but never doing anything about it and rejecting people who try to help.

Interested in abusive relationships in which the patient may be abused and humiliated. Tend to hold back and show no pain.

Feeling trapped in an endless cycle of self-loss. Feeling unable to feel pleasure without guilt/shame and feeling hopeless about the future patient may be abused and humiliated.

Sexual fantasies about hurting adults, children, or animals. This fantasy will last for a long period of time, which is about 6 months.

G018 In their sexual fantasies, the sufferer acts as a dominant who acts to hurt his sex partner In a more advanced phase, the sufferer will try to do the hurtful act for real, no longer a fantasy in his mind

G020 Sexually hurting for gratification is done by hitting, cutting, burning, biting, and whipping. From time to time, the level of hurting their sex partners will increase to get more sexual satisfaction

G022 Intense and frequent fantasies or sexual urges toward children 13 years of age or younger

Feeling uncomfortable and unable to move smoothly due to the conditions experienced. For example, difficulties in work, family relationships, or interacting with other people.

Sufferers also generally manifest their sexual desires by taking action on victims who still have a relative or close relationship with them, including nephews, stepchildren, and so on.

G025 The fetish lasts for more than 6 months and occurs continuously.

G026 Sexual urges don't just exist in the mind, they have been put into practice.

G027 Sexual urges are hard to control

G028 Sexual behavior interferes with daily life

G029 Feeling intense and repeated arousal when wearing clothes of the opposite sex 


\begin{tabular}{ccc}
\hline Code & Symptoms Disease & Diseases \\
\hline G032 & Experiencing this condition for 6 months or more & \\
\hline
\end{tabular}

d. Rule Base

TABLE 4

RULE BASE

\begin{tabular}{cll}
\hline No & \multicolumn{1}{c}{ IF } & \multicolumn{1}{c}{ THEN } \\
\hline 1 & G001, G002 & Voyeuristic Disorder (P001) \\
2 & G003, G004, G005 & Exhibitionistic Disorder (P002) \\
3 & G006, G007, G008 & Frotteuristic Disorder (P003) \\
4 & G009, G010, G011, G012, G013, G014, G015, G016 & Sexual Masochim Disorder (P004) \\
5 & G017, G018, G019, G021 & Sexual Sadism Disorder (P005) \\
6 & G022, G023, G024 & Pedophilic Disorder (P006) \\
7 & G025, G026, G027, G028 & Fetishistic Disorder (P007) \\
8 & G029, G030, G031, G032 & Transvestic Disorder (P008) \\
\hline
\end{tabular}

\subsection{Case Examples} as follows:

An example of an analysis of the diagnosis of sexual disorders (paraphilia) entered by the user is

a. Determine the Symptoms Experienced by the Patient

Suppose a patient chooses some of the symptoms of the disease he is experiencing, namely:

1) G001 : Experiencing intense and repeated sexual arousal from peering at others who are undressed, undressed, or engaged in sexual activity for six months as a manifestation of fantasies, urges or actions, supports disease P001

2) G002 : Usually will peek while fantasizing sexually and masturbating, but not interested in having sex with the person being peeked at, supports disease P001

3) G013 : Feeling unable to say no or to assert oneself, instead of agreeing with grumbling

b. Application of the Dempster Shafer Method

After selecting or inputting several types of symptoms of sexual disorders experienced by the user (patient), the next step for the system is to analyze the calculation by applying the Dempster Shafer method, which is as follows:

1) For Symptom Choice 1 (G001)

Then: $\mathrm{M} 1\{\mathrm{P} 001\}=0.80$

$\Theta=1-0.80=0.2$

2) For Symptom Choice 2 (G002)

Then: $\mathrm{M} 2=\{\mathrm{P} 001\}=0.70$

$\theta=1-0.70=0.3$

TABLE 5

DETERMINATION OF INITIAL DENSITY (M)

\begin{tabular}{clccc}
\hline \multirow{2}{*}{ No } & \multicolumn{1}{c}{ Symptoms } & Disease & Delief & Plausability \\
\cline { 4 - 5 } \cline { 4 - 4 } 1 & $\begin{array}{l}\text { Experiencing intense and repeated sexual } \\
\text { arousal from peering at others who are } \\
\text { undressed, undressed, or engaged in sexual } \\
\text { activity for six months as a manifestation of } \\
\text { fantasies, urges or actions, supporting illness }\end{array}$ & & 0.80 & 0.2 \\
$\begin{array}{l}\text { Usually will peek while fantasizing sexually and } \\
\text { masturbating, but not interested in having sex } \\
\text { with the person being peeked at, supports } \\
\text { disease }\end{array}$ & P002 & 0.70 & 0.3 \\
\hline
\end{tabular}


c. For Symptoms Option 3 (G013)

If the symptom selected by the user is more than 2 (two) symptoms, then the next step is to look for the combination of symptoms of the disease. To facilitate the calculation, the subsets formed are entered into the table. The first column is filled with the first symptom (M1). While the first line is filled with the second symptom (M2). So that the value of M3 is obtained as a result of the combination of M1 and M2.

TABLE 6

COMBINATION RULES FOR M3

\begin{tabular}{|c|c|c|c|c|}
\hline & $\{\mathrm{P} 001\}$ & $(0.7)$ & $\theta$ & $(0.3)$ \\
\hline$\{\mathrm{P} 001\}(0.80)$ & $\{\mathrm{P} 001\}$ & $(0.56)$ & $\{\mathrm{P} 001\}$ & $(0.24)$ \\
\hline$\theta \quad(0.2)$ & $\{\mathrm{P} 001\}$ & $(0.14)$ & $\theta$ & $(0.06)$ \\
\hline
\end{tabular}

$$
\begin{aligned}
& M_{3}\{P 001\}=\frac{0.56+0.14}{1-0.06}=\frac{0.7}{0.94}=0.744 \\
& M_{3}\{P 001\}=\frac{0.24}{1-0.06}=\frac{0.24}{0.94}=0.255 \\
& M_{3}\{\theta\}=\frac{0.06}{1-0.06}=\frac{0.06}{0.94}=0.063
\end{aligned}
$$

From the calculation results of the combined M3 density value above, it can be seen that the \{P001\} value is higher than the other symptoms with a density of 0.744 . If then there are other symptoms, namely: Feeling unable to say no or to assert oneself, instead of agreeing by grumbling inwardly (M4 \{P001,P002,P003,P004\}), then a calculation must be made for the new density of M5. M4 as a function of density. So that the value of M5 is obtained as a result of M combination. $\mathrm{M}_{4}\{\mathrm{P} 001, \mathrm{P} 002\}=0.40$ $\mathrm{M}(\theta)=1-0.40=0.6$

TABLE 7 COMBINATION RULES FOR M5

\begin{tabular}{ccccc}
\hline & $\{\mathrm{P} 001, \mathrm{P} 002\}$ & $(0.4)$ & $\Theta$ & $(0.6)$ \\
\hline$\{\mathrm{P001}\}(0.744)$ & $\{\mathrm{P} 001\}$ & $(0.297)$ & $\{\mathrm{P} 001\}$ & $(0.446)$ \\
$\{\mathrm{P} 001, \mathrm{P} 002, \mathrm{P} 003, \mathrm{P} 004)$ & $\{\mathrm{P} 001, \mathrm{P} 002\}$ & $(0,102)$ & $\{\mathrm{P} 001, \mathrm{P} 002, \mathrm{P} 003, \mathrm{P} 004\}$ & $(0.153)$ \\
$\Theta \quad(0.063)$ & $\{\mathrm{P} 001, \mathrm{P} 002\}$ & $(0.25)$ & $\Theta$ & $(0.0378)$ \\
\hline
\end{tabular}

Based on the calculation of the combination rules for M5 above, it can be obtained:

$$
\begin{aligned}
& M_{5}\{\mathrm{P} 001\}=\frac{0.297+0.446}{1-0.0378}=\frac{0.743}{0.9622}=0.772 \\
& M_{5}\{\mathrm{P} 001, \mathrm{P} 002\}=\frac{0.102+0.025}{1-0.0378}=\frac{0.127}{0.9622}=0.131 \\
& M_{5}\{\mathrm{P} 001, \mathrm{P} 002, \mathrm{P} 003, \mathrm{P} 004\}=\frac{0.153}{1-0.0378}=\frac{0.153}{0.9622}=0.159
\end{aligned}
$$

From the results of the calculation of the combined M5 density value above, it can be seen that the results of sexual disorders (paraphilia) with the type of Voyeuristic Disorder (P001) with a probability value or confidence value of 0.772 or if the percentage becomes $77.2 \%$. This research was conducted at MTS Swasta YPII Kotarih, this study used passive particion observations. The data obtained from the data of class VII students in the odd semester of the 2020/2021 academic year, the number of student data taken as a sample is 142 people. The output in this study is divided into two categories, namely Excellent Students and Not. Based on the output to be generated, the authors use classification techniques. 


\section{Conclusion}

Based on the results of the decision tree above, there are 19 rules that were tested, the data testing was based on the 19 rules that had been set, from 142 data tested $73.94 \%$ : 26.06\%, 105 data were appropriate and 37 data did not match. Application of the C4.5 Algorithm in classifying using a decision tree. The C45 algorithm is used to analyze student assessments in semester 7 of 2020/2021, the student data is applied to the KDD stages starting from data selection, Pre-Processing, Transformation, Data Mining, and Evaluation, by classifying which students are superior students, so that placement students who enter the superior class according to the achievements achieved.

\section{References}

Bhaskara, K., Hidayat, N., \& Muflikhah, L. (2019). Sistem Diagnosis Penyakit Kelamin Pada Pria Menggunakan Metode Forward Chaining Dan Dempster-Shafer. Jurnal Pengembangan Teknologi Informasi Dan Ilmu Komputer E-ISSN, 2548, 964X.

Daud, F. K. (2016). PARAFILIA: NATURE ATAU NURTURE? TINJAUAN TEOLOGIS DAN PSIKOLOGIS. Al-A'raf: Jurnal Pemikiran Islam Dan Filsafat, 13(2), 283-311.

Gozali, S. A., \& Jollyta, D. (2019). Metode Dempster Shafer untuk Mendeteksi Penyakit Mental Disorder: Skizofrenia dan Psikotik. Jurnal Mahasiswa Aplikasi Teknologi Komputer Dan Informasi (JMApTeKsi), 1(2), 104-109.

Hairani, H., Kurniawan, K., Abd Latif, K., \& Innuddin, M. (2021). Metode Dempster-Shafer untuk Diagnosis Dini Jenis Penyakit Gangguan Jiwa Skizofrenia Berbasis Sistem Pakar. Sistemasi: Jurnal Sistem Informasi, 10(2), 280-289.

Hastari, D., \& Bimantoro, F. (2018). Sistem pakar untuk mendiagnosis gangguan mental anak menggunakan metode dempster shafer. Jurnal COSINE, 2.

Rahmadhani, A., Fauziah, F., \& Aningsih, A. (2020). Sistem Pakar Deteksi Dini Kesehatan Mental Menggunakan Metode Dempster-Shafer. SISFOTENIKA, 10(1), 37-49.

Sembiring, N. S. B., \& Sinaga, M. D. (2017). Penerapan Metode Dempster Shafer Untuk Mendiagnosa Penyakit Dari Akibat Bakteri Treponema Pallidum. CSRID (Computer Science Research and Its Development Journal), 9(3), 180-189.

Utomo, D. W., \& Suprapto, N. H. (2017). Pemodelan Sistem Pakar Diagnosis Penyakit pada Sistem Endokrin Manusia dengan Metode Dempster-Shafer. Jurnal Pengembangan Teknologi Informasi Dan Ilmu Komputer E-ISSN, 2548, 964X.

Wiyandra, Y. (2019). SISTEM PAKAR GINEKOLOGI DENGAN METODE FORWARD CHAINING DAN CERTAINTY FACTOR. JOISIE (Journal Of Information Systems And Informatics Engineering), 3(2), 71-78.

Yuwono, D. T., Fadlil, A., \& Sunardi, S. (2019). Comparative Analysis of Dempster-Shafer Method and Certainty Factor Method On Personality Disorders Expert Systems. Scientific Journal of Informatics, 6(1), 12-22. 